Page 373-387. ISBN: 978-602-6 988-75-1

Web Jurnal Online: jurnal.unmuhjember.ac.id

By: Mochamad Faizal R.;Fabya Budi Luthfiana

Governance Innovation In Tourism Development

Margacinta Village, Pangandaran Regency

\title{
GOVERNANCE INNOVATION IN TOURISM DEVELOPMENT MARGACINTA VILLAGE, PANGANDARAN REGENCY
}

\author{
Mochamad Faizal Rizki ${ }^{1}$ \\ Fabya Budi Luthfiana ${ }^{2}$ \\ mochamad.faizal@fisip.unsika.ac.id \\ fabyabudi1899@gmail.com
}

\begin{abstract}
The village as mandated by the Law has the obligation to preserve and advance the customs, traditions, and culture of the community. The Village Government must be able to encourage the initiatives, movements, and participation of the village community to develop the village's potential and assets for mutual welfare. This paper aims to identify the implementation of governance innovations that include new types of leadership, technical and management capabilities, the strength of civil society, space for participation in developing Margacinta Village as a cultural village so that it becomes the leading tourism destination in Pangandaran Regency. The method used in this study is observation and interviews with the Village Head and the manager of cultural tourism in Margacinta Village.
\end{abstract}

Keywords: innovation of governance, village culture, tourism

\footnotetext{
${ }^{1}$ The author is a lecturer in the Government Science, University of Singaperbangsa Karawang. email: mochamad.faizal@ fisip.unsika.ac.id

${ }^{2}$ The author is a student in the Government science, University of Singaperbangsa Karawang. Email: fabyabudi1899@gmail.com
} 
Proceeding ICOGISS 2019

Page 373-387. ISBN: 978-602-6 988-75-1

Web Jurnal Online: jurnal.unmuhjember.ac.id

By: Mochamad Faizal R.;Fabya Budi Luthfiana

Governance Innovation In Tourism Development

Margacinta Village, Pangandaran Regency

\subsection{Introduction}

The paradigm of sustainable development which is the foundation of development has penetrated all fields, the concept being adopted one of them into sustainable tourism development can be interpreted as a tourism development process oriented to the sustainability of the resources needed for future development. Three components to support the implementation of sustainable tourism development is the first means the need to protect natural resources from the negative impacts of tourism activities. Secondly, Social Adaptability, in accordance with the group's ability to absorb tourists without causing disharmony in social relations, both among members of the community group with tourists, or between fellow members of the group. Third, Cultural Sustainability, in this context assumes that the impact of the presence of tourists in a tourist destination does not have a negative impact on the development of local culture, but that the existence of the culture must be maintained for future generations and even become a tourist attraction (Fitra Dkk, 2001)

Tourism is one of the strategic sectors given the diverse potential of Indonesian culture and nature so that it attracts tourists both domestically and abroad to come. Tourism according to law no. 102009 is a variety of tourism activities and is supported by various facilities and services provided by the community, businessmen, government and regional government. While according to Yoeti (1996) defines that tourism is a journey carried out for a while, held from one place to another, with the intention not to try or make a living in a place visited, but solely to enjoy the trip for sightseeing, and recreation or to fulfill the diverse. From this, definition, tourism can be interpreted as an activity carried out by humans that aims at recreational facilities as one of the needs. With the development of the tourism sector, the country's foreign exchange has increased as evidenced in 2018 the country's foreign exchange revenue from the tourism sector amounted to 16.1 billion US \$, up from 15 billion US \$ 2017 data (Katadata.co.id). From this figure, it can be seen that there is an increase of 1.1 billion US \$ in one year, meaning that the development of domestic tourism can contribute significantly to state revenues. From BPS data as domestic tourism develops, an increase in the Hotel Occupancy (TPK) rate of star classification in Indonesia in December 2017 reached an average of 59.53 percent, up 3.03 points compared to the December 2016 TPK of 56.50 percent. In addition, in terms of the public transportation sector, there has also been an increase and improvement, most of the train users in 2017 are 36.8 million people. This means the impact of local tourism developments can affect the development and improvement of the community economy both on a macro and micro scale.

In line with the development of the tourism sector which contributed foreign exchange, it was influenced by the existence of regional autonomy with the enactment of Law number 23 of 2014, so that the regions had the right to develop the potential of their region especially the development of tourism villages. With the development of the tourism industry, there is a shift in the concept of a world tour to 
Proceeding ICOGISS 2019

Page 373-387. ISBN: 978-602-6 988-75-1

Web Jurnal Online: jurnal.unmuhjember.ac.id

By: Mochamad Faizal R.;Fabya Budi Luthfiana

Governance Innovation In Tourism Development

Margacinta Village, Pangandaran Regency

the ecotourism model, due to the saturation of tourists to visit artificial tourism objects. Therefore this opportunity should be fully utilized to attract foreign tourists to visit objects based on the nature and culture of local residents (Dias, 2009)

West Java Province in particular Pangandaran Regency has long been known as an area that attracts tourists because of its natural potential. Data from BPS in 2016 amounted to 1,834,711 tourists, still below Bandung and Bogor Regencies. This potential that is approved can be maximized by ecotourism and culture-based development. Of the 4 destinations in Pangandaran Regency, Margacinta Village is one of the attractive destinations only as developing ecotourism but has special potential Badud Village which consists of art, culinary and handicrafts that are interesting, on the other hand the rich natural potential will vary biodiversity and artificial innovation so that it can be known and visited by the wider community this potential is also needed for the benefit of cultural preservation and economic improvement of the community.

Cultural tourism is not only a trip and activities to enjoy culture, but also other activities carried out by other parties related to these tourists. Related to various efforts that need to be carried out, it continues to run by attracting unique, limited and non-renewable resources (Winoyoputri, 2005). In Badud village itself, a culture that was internalized in the lives of its people, changes in the form of various kinds of villages, which only relied on natural gifts, but the people were aware of their cultural preservation.

In tourism development, Margacinta Village requested governance assistance related to new types of leadership, technical and management capabilities, strengthening civil society, space for participation in developing villages to become a leading tourist destination in Pangandaran Regency. (Sumarto, 2009)

The formulation of the problem from this research is about the application of governance in the development of Margacinta Village, Pangandaran Regency? While the purpose of the discussion of this article is to evaluate and analyze the implementation of governance innovations in developing tourism in Margacinta Village, Pangandaran Regency. Benefits that researchers:

1. Theoretically, this research is expected to be useful as a material for the development of insights and knowledge relating to the study of governmental sciences, especially with regard to the development of the theory of governance innovation

2. Practically this research is expected to be used as input material for local governments, especially the Margacinta Village government, related to the optimization of the application of innovation in developing tourism. 
Page 373-387. ISBN: 978-602-6 988-75-1

Web Jurnal Online: jurnal.unmuhjember.ac.id

By: Mochamad Faizal R.;Fabya Budi Luthfiana

Governance Innovation In Tourism Development

Margacinta Village, Pangandaran Regency

\subsection{Research Methods}

The design of this study is qualitative research that intends to understand the phenomenon of what is experienced by research subjects holistically by means of descriptions in the form of words and languages in a specific natural context by utilizing various natural methods (Moleong, 2012: 6). In a qualitative approach, researchers try to observe and uncover the realities that occur in the field relating to the implementation of governance innovations in the development of tourism in Margacinta Village, Pangandaran Regency. This study also uses descriptive methods to explore and clarify a phenomenon or social reality by describing a number of variables relating to the problem and the unit under study. The data collected in this study contained two types of data, namely primary and secondary. Primary data are collected from participant observation and interviews with the Margacinta Village government in Pangandaran Regency and the community while secondary data is obtained from literature data and results of studies related to governance innovations in tourism development in Margacinta Village, Pangandaran Regency. The technique of determining informants uses purposive sampling technique, which is to determine the informants who are considered to be the most knowledgeable, making it easier for researchers to explore the objects or social situations under study. The technique of collecting data uses interviews, observation, and documentation. Data analysis techniques used by researchers with data reduction, data presentation and conclusions, and data validity techniques.

\subsection{Research Results}

This research was conducted to focus on efforts to study more about the innovation governance in the development of tourism in Margacinta Village, Pangandaran Regency to respond to the potential of nature and culture that can be maximized. In this study, the author uses the theory of governance innovation which consists of four indicators, first is the new type of leadership, the strength of civil society, technical \& management innovation and space for participation. 
Proceeding ICOGISS 2019

Page 373-387. ISBN: 978-602-6 988-75-1

Web Jurnal Online: jurnal.unmuhjember.ac.id

By: Mochamad Faizal R.;Fabya Budi Luthfiana

Governance Innovation In Tourism Development

Margacinta Village, Pangandaran Regency

\section{Framework for Government Governance Innovation Theory}

According to Chotray and Stoker, innovation in governance is a process of change towards better governance covering many actors in a public organization (Teguh, 2016). This means that the old system has been abandoned because it is not in accordance with the challenges of the times and current conditions of society. In governance innovation, the government itself has a central role in efforts to empower the community through strong legitimacy. Basically, the purpose of the government is to the welfare of the people, but what method is most appropriate to be formulated because often the government as an actor in managing government is not providing solutions to problems and development in the community but is part of the problem.

As the rules regarding regional autonomy have evolved as an optimization of the role of regional governments, in particular, to maximize the potential of villages owned, according to the village law number 6 of 2014 other sources of income that can be cultivated by the Village come from Village Owned Enterprises, Village market management, management of village-scale tourism areas, management of non-metal mineral mines and rock mines by not using heavy equipment, as well as other sources and not for sale. The climate of innovation will be more conducive when the central government provides flexibility and valuable incentives for regions to develop innovative ideas. In order to transmit innovations that have been developed by the city-district and also in giving assistance and reducing resistance in the region (Sumarto, 2009)

The concept of ecotourism usually has strong conservation characteristics in both social and environmental aspects. Wisdom, experience and cultural values are so integrated with the environment to support economic life (Nugroho and Dahuri, 2004).

Ecotourism as a form of government efforts to realize innovation in governance in developing tourism in Margacinta Village. According to Hetifah SJ Sumarto, so that governance innovation can take place well there are four indicators, namely:

1. The new type of leadership

2. Strength of civil society

3. Innovation concerns technical and management capabilities

4. Innovation and participation space

Seeing the natural and cultural potential in Margacinta Village which has developed with the innovation of the village government so that it encourages the involvement of the community to preserve the culture and participate in promoting various kinds of tourism products that change the old ways in the tourism industry through the concept of ecotourism. 
Page 373-387. ISBN: 978-602-6 988-75-1

Web Jurnal Online: jurnal.unmuhjember.ac.id

By: Mochamad Faizal R.;Fabya Budi Luthfiana

Governance Innovation In Tourism Development

Margacinta Village, Pangandaran Regency

\begin{tabular}{|l|l|l|l|}
\hline $\begin{array}{l}\text { Development of } \\
\text { tourism with the } \\
\text { concept of } \\
\text { sustainable } \\
\text { tourism } \\
\text { development } \\
\text { (Ecological } \\
\text { Sustainability, } \\
\text { Social } \\
\text { Adaptability, } \\
\text { Cultural } \\
\text { Sustainability) }\end{array}$ & $\begin{array}{l}\text { Governance innovation } \\
\text { in Tourism } \\
\text { Development } \\
\text { Margacinta Villages, } \\
\text { includes: } \\
\text { 1. New type of } \\
\text { leadership } \\
\text { 2. Strength of Civil } \\
\text { Society } \\
\text { 3. Managerial Technical } \\
\text { Ability } \\
\text { 4. Participation Room } \\
\text { (Sumarto: 2009) }\end{array}$ \\
\hline
\end{tabular}

\subsubsection{Transformative Leadership Paradigm}

Leadership means the ability and personality of a person in influencing and persuading other parties to take action to achieve common goals so that the concerned becomes the beginning of the structure and center of the group process. Although it has the same purpose, the way to influence its members can be different from the background of the leadership style possessed by the personal leader. This means that leadership does not only mean the ability to lead but also how the capacity of leaders at the local level to interact with their citizens. (Seftyono et al, 2016)

This research related to the leadership of the village head Margacinta, the authors see that the leadership style applied in developing tourism is related to the type of transformational leadership defined as leadership that includes organizational change efforts (as opposed to leadership designed to maintain the status quo). It is believed that this style will lead to superior performance in organizations that are facing the demands of renewal and change (Handoko and Tjiptono: 1996).

The essence of leadership applied by the head of Margacinta Village is that sharing of power involves subordinates together to make changes by applying various managerial practices, they are able to empower the subordinates of society in other words, they can significantly strengthen people's beliefs in their own abilities. 
Page 373-387. ISBN: 978-602-6 988-75-1

Web Jurnal Online: jurnal.unmuhjember.ac.id

By: Mochamad Faizal R.;Fabya Budi Luthfiana

Governance Innovation In Tourism Development

Margacinta Village, Pangandaran Regency

The applied democracy was manifested in the visionary leadership but also involved the Margacinta Village community for the sake of prosperity and mutual progress. That is, the village government is not only fixated on the top down the system and the community only runs a variety of innovative big ideas but cultivates a bottom-up system, which changes the public perception that tourism potential is shared. Tichi and Devanna (Luthans, 1995) found various characteristics of transformational leaders as follows:

1. They identify themselves as agents of change.

2. They are brave and firm.

3. They believe in others.

4. They are value-driven.

5. They are lifelong learners.

6. They have core abilities to face complexity and uncertainty.

7. They are visionary.

Leadership is interpreted as one of the important indicators in community capacity building and community resilience (Madsen and O'Mullan: 2014). Given the important role of the village head, interactions are built with the community to realize sustainable tourism development programs that can be controlled by residents. As a change agent, the head of Margacinta Village realizes that this village does not have a coastline like other villages in Pangandaran, therefore shifting the concept of tourism towards ecotourism by optimizing tourism products and services in natural and cultural concepts begins to be initiated to attract tourists. Because culture is the result of human creation, work, and intention as a form of self-actualization that reflects the knowledge and habits of the people.

The leadership of the village head of Margacinta is brave and resilient, this can be realized from various programs formulated to promote Margacinta Village as a tourism village. Determination to believe that this village will advance with the potential of nature and culture that are packaged in educational tourism and dare to account for the output of policy.

The village head trusts the community to develop because tourism based on ecotourism and culture is part of the daily lives of the people, the next step is how that trust can be arranged to become the satisfaction of various layers of society. The value directed by the village head is a reference in cultural preservation, but on the other hand, it can develop an economy based on the people and for the people. Understanding that in tourism development there needs to be program optimization, the leadership of the village head requires periodic evaluations and studying the development of the tourism world so that learning is not stopped at the promotion stage, but there are still other ongoing adaptation processes. 
Proceeding ICOGISS 2019

Page 373-387. ISBN: 978-602-6 988-75-1

Web Jurnal Online: jurnal.unmuhjember.ac.id

By: Mochamad Faizal R.;Fabya Budi Luthfiana

Governance Innovation In Tourism Development

Margacinta Village, Pangandaran Regency

Looking at tourism as an industry, it is inseparable from uncertainty considering that most visitors who come when there are not every day and leaders who are unable to innovate will find it difficult to develop. In the broader context of innovation, village leaders are also required to develop social capital, because social capital is an important factor in relation to economics and development (Farr: 2004). The village head of Margacinta who is visionary can be seen from long-term thinking to adapt to technological developments so that tourism promotion is done through social media because it reaches all levels of society

\subsubsection{Community Based Tourism (CBT)}

The concept of community-based tourism is the basis of sustainable tourism development which confirms that society is no longer an object of development but as a determinant of development itself and is involved in the formulation to policy making (Ardika, 2005). The concept of Community Based Tourism (CBT) or tourism based on local communities is a concept that prioritizes the involvement of local communities in tourism development as explained by SNV Netherland Development Organization (2009) that Community-based tourism is part of cultural tourism that is initiated, owned, and run by local people (generally by rural communities, the poor, and marginalized communities).

The establishment of community-based tourism is one of the implementations of the great idea of civil society as one form of empowerment that is formed to enhance the role of local communities with expertise and knowledge that is useful in leading tourism services. In connection with the existence of a strong civil society, there is a term that has become popular, namely social capital, which is one form of capital that is very valuable in addition to financial, physical and human capital. Social capital is an interhuman process that forms networks, norms, social trust and facilitates coordination and cooperation for mutual benefits (Sumarto, 2009).

The community in Margacinta Village knows the district-level tourism activator group (Kompepar Pangandaran) who has been acting as a supporter by providing concepts and inputs to launch Badud Village art into its cultural icon in Pangandaran Regency, According to the Chairperson of Kompepar Edi Rusmiadi explaining that efforts to realizing the Badud village became an icon of Pangandaran Regency planned and discussed by several stakeholders, especially village heads who played an active role in preserving badud culture but the reality is that all return to assistance from the local government and the community in Margacinta Village itself as an activity. Kompepar Pangandaran also formed a unit in Margacinta Village as an extension of the district level to the village so that its performance could run optimally. Kompepar Pangandaran related to development in Margacinta Village, after conducting interviews with the Chairperson of Margacinta Village Kompepar, Asep Kartiwa and Chairperson of the Pangandaran Arts Council who also dealt with the communities and communities of Margacinta Village, as well as Kompepar Margacinta, tried to: 
Proceeding ICOGISS 2019

Page 373-387. ISBN: 978-602-6 988-75-1

Web Jurnal Online: jurnal.unmuhjember.ac.id

By: Mochamad Faizal R.;Fabya Budi Luthfiana

Governance Innovation In Tourism Development

Margacinta Village, Pangandaran Regency

1. As a pioneer, it means inspiring people to benefit local culture and beauty so that it can become a leading tourism potential

2. As an activator, it means actively participating in efforts to change and invite other people to be involved in efforts to make Margacinta Village a tourist village

3. As a director, meaning guiding and directing the community for the process of organizing tasks in tourism development activities

4. Facilitation with the government, intended as a forum for public aspirations or relations to the government

5. As a marketer, it means that Kompepar Desa Margacinta promotes both art and its natural potential through various media

However, in the implementation, there was enthusiasm from the village community or each hamlet which was relatively small in the implementation of tourism activities in Margacinta Village. It was seen a compilation of Badud senior performances in the margajaya hamlet, only those hamlets that moved and were assisted by hamlets such as Cidawung and Pangancaraan maximally preferred if the art performances and tourism activities in Margacinta Village are enlivened by all the villagers, either as an audience or as an actor so that the sense of belonging to the cultural and tourist potentials in Margacinta Village does not only belong to a few people and hamlets but belongs to the entire village community. Belonging to the entire village community, it is also a reflection where the potential needed is an asset that is able to provide positive benefits for the community and of course the most important are the cultures in the village which are nations that need to be preserved so that they are not extinct by the globalist era The icon of ASI but developed into Pangandaran Regency and the State of Indonesia is still a rare art that exists in other regions, this is an area of pride that should be visited by all parties.

\subsubsection{Tourism Product Innovation}

Developing ecotourism services in an area needs to find a position taken like Bali. This marketing strategy requires the support of product development, market segmentation, and marketing technology. The level of development of products and services is related to interpretive activities, namely efforts to understand the object so that someone is able to argue and bring out a positive relationship between humans and the object/nature. Without interpretation, ecotourism activities are not optimal or produce output like tourism activities in general. In such circumstances, ecotourism activities are still tinged with activities that protect environmental sustainability, including promoting firewood (2.1\%) and other forest products (2.8\%), and hunting tourism (3.5\%) (Goodwin, 2002). The threat is even greater in areas with high population density and without entrepreneurial skills. (Nugroho and Dahuri, 2012).

In Margacinta Village, entrepreneurship skills in tourism products are empowering the community to have the opportunity to achieve a prosperous life, between tourism products, namely: 
Proceeding ICOGISS 2019

Page 373-387. ISBN: 978-602-6 988-75-1

Web Jurnal Online: jurnal.unmuhjember.ac.id

By: Mochamad Faizal R.;Fabya Budi Luthfiana

Governance Innovation In Tourism Development

Margacinta Village, Pangandaran Regency

1. Art, in terms of art tourism products, consist of:

a) Badud Buhun (Ancient)

One type of traditional art that is closely related to social and cultural life as its support is Badud Arts. Badud is the name of the term used to repel pests or pest plants, especially rice in rice fields. Badud Arts are in Margajaya Hamlet, Margacinta Village, Cijulang Subdistrict, Pangandaran Regency. This Badud art is a folk art by repeating (singing) certain songs to repel rice pests in the paddy fields in order to obtain a large rice harvest, and also to carry out events to parade rice from rice fields, and this art is usually done together so that rousing. Although this buhun art is classified as a long-standing and seemingly conservative belief, performances combined with audio and good promotions have attracted tourists. However, it is undeniable that there are still shortcomings in innovating Badud arts, among others, based on the results of interviews with the Margacinta Village Head, the problems faced in developing this cultural tourism are (1) Lack of Human Resources (2) Cultural preservation (3) Community preparation in carrying out tourism activities.

b) Buhun Gondang Arts

Gondang, in general, is a musical artist whose tone is produced from gondang (a place to pound rice) and alu (pounding stick). The players are 15 women, and because this is Gondang Buhun, those who play it are female elders who have long preserved Gondang art. The song played in ancient Sundanese was even less familiar to Sundanese people. But with show innovation equipped with audio support so that it can be enjoyed clearly by tourists. In the tradition of Gondang Buhun, there are three elements, namely: pestle, mortar, and kakawihan (poetry) sung. Alu serves as a rice pounder, mortar serves as a container of rice, and kakawihan is a poem that accompanies the women who play Gondang Buhun in the performance of rice processing into the rice. Gondang Buhun's art preservation activities are routinely carried out through training activities once a week, as well as actively participating in art festivals organized by villages, subdistricts, regencies, or as art contingents representing Pangandaran District at the provincial level. (Emilda Dkk, 2016)

c) The Wayang Golek Art

Wayang golek performances in Margacinta Village are also often displayed in formal and informal events both commemorating the Birthday of the Prophet Muhammad or the celebration of marriage and circumcision of the community and in Pangandaran Regency itself if there is a cultural event held by the Regional Government interspersed with wayang golek. Although puppet shows have long been known, village governments and communities have innovated in promoting puppet shows so that visiting tourists can enjoy them. 
Proceeding ICOGISS 2019

Page 373-387. ISBN: 978-602-6 988-75-1

Web Jurnal Online: jurnal.unmuhjember.ac.id

By: Mochamad Faizal R.;Fabya Budi Luthfiana

Governance Innovation In Tourism Development

Margacinta Village, Pangandaran Regency

\section{d) Angklung Toel}

This Angklung is a development or innovation on Badud musical instruments. But Mang Koko who is the founder of Saung Angklung Mang Koko modified the shape of a modern angklung toel. Angklung which is usually played is usually moved sideways, but the Mango now creates an angklung that can be moved like playing the piano, and Mang Koko named the angklung with angklung toel, but the sound produced by angklung toel does not change the original sound of the angklung, only the change is how to play the angklung.

e) Kliningan art

The art of innovation in the combination of gamelan coupled with the strains of fiddle music instruments accompanied by a scribe consisting of sinden and Swara wira.

2. Typical Handicrafts of Kampung Badud

In the village of Badud the typical souvenirs of Kampung Badud are diverse and are mostly made of bamboo and wood.

a) Kolotok

Kolotok is a key chain shaped like a small bell made of bamboo and emits a distinctive sound. Kolotok is usually used in livestock but in Kampung Badud it is innovating so that it can be used as a unique and interesting souvenir.

b) Kamuti

Kamuti is a traditional bag that innovates by utilizing natural resources made from gebang trees with the process of making in weaving so as to make bagshaped artworks that are characteristic of Pangandaran Regency.

c) Bracelets

This woven bracelet originating from Badud Village does not yet have an official name, but the material from this plait is a unique innovation of the hata tree that grows in the village of Margacinta.

3. Culinary

a) Liwet Jolem

Liwet Jolem comes from the Sundanese language which stands for Kejo and Nilem (rice and nilem fish) or another name is Kejo Pelem (delicious rice) which is a dish of liwet rice but different from liwet rice which is usually served by people in other West Java areas. This Liwet Jolem is a combination of Liwet rice with spices or Pindang (Pepes) fish, but there are other innovations using shells and according to Bapak Entis from Kompepar Margacinta with many of these variations besides the Jolem dishes are better, tourists are also curious about the menu and offerings.

b) Cau Heart Nugget (Banana)

In Badud village itself, the use of banana heart innovates so that it has its own processed nugget, namely nugget made from the heart of a banana tree. The shape is similar to the usual nugget shape, however, from a rather blackish color 
Proceeding ICOGISS 2019

Page 373-387. ISBN: 978-602-6 988-75-1

Web Jurnal Online: jurnal.unmuhjember.ac.id

By: Mochamad Faizal R.;Fabya Budi Luthfiana

Governance Innovation In Tourism Development

Margacinta Village, Pangandaran Regency

texture and taste that does not fully taste the heart of a banana tree because of the combination of the flesh and heart of the banana tree.

c) Honje juice

In Kampung Badud, Honje is not only used as a spice for cooking but innovating into a traditional beverage for the Badud community. The making of this juice does not use any honje, because according to the residents the honje juice is made using honje laka, which is honje which only grows in Kampung Badud.

In Margacinta Village, in addition to cultural tourism attractions, there is also an innovative natural tourist attraction, including Cijulang rafting, which previously had not yet been available, then innovated so that not only natural beauty in the form of river flow but rafting tools such as rubber boats, canoes, like, available so tourists feel safe when traveling. In addition, there are mushroom cultivation and bee cultivation, mangrove forests, camping ground, metro cross motorbike circuits and tours of natural caves. All of them innovate by providing facilities and infrastructure and services that are continually being improved.

\subsubsection{Cultural Instruments of Participation}

Mubyarto (1984: 35) defines participation as a willingness to help the success of each program is in accordance with the capabilities of each person without means of sacrificing self-interest. According to other experts, the substance of participation is the work of a government system where no policy is taken without the consent of the people, while the basic direction to be developed is the empowerment process, further said that the purpose of developing participation is: First, participation will allow the people independently (autonomously) organize themselves, and thus will make it easier for the public to face difficult situations, and be able to reject various adverse tendencies. Second, participation is not only a concrete mirror of the opportunities for expressing aspirations and ways to fight for it but more importantly, participation becomes a guarantee for not ignoring the interests of the people. Third, that the problems in the dynamics of development will be overcome by community participation (Juliantara, 2002).

In Margacinta Village, Pangandaran Regency, community participation in tourism development can be seen from involvement in planning to the evaluation stage in the formulation of a typical tourism development program in Kampung Badud. Due to limited funding, making traditional house concepts that have been planned for tourists to spend the night in Badud village has not been realized, therefore community participation can be seen from the involvement of making their home a homestay if tourists are interested in staying at Badud Village. To increase community participation in the development of the culture of Badud village, supporting facilities and infrastructure are needed in the construction of involving the community to work together to create a pavilion that functions as a place to organize regional arts and also functions for village activities such as welcoming guests. In welcoming guests or tourists the community is involved so that there is a sense of belonging and representation of Kampung Badud's 
Proceeding ICOGISS 2019

Page 373-387. ISBN: 978-602-6 988-75-1

Web Jurnal Online: jurnal.unmuhjember.ac.id

By: Mochamad Faizal R.;Fabya Budi Luthfiana

Governance Innovation In Tourism Development

Margacinta Village, Pangandaran Regency

hospitality. The pavilion can also be used to hold a minggon meeting in the evaluation of tourism development in Kampung Badud and followed by the Margacinta Village apparatus, traditional leaders and the community to discuss the inhibiting factors of tourism development and the aspirations of the people who are accommodated for a joint solution. So that the output of the minggon meeting can be seen from improvements in tourism development both in terms of services provided and supporting facilities and infrastructure. The five saung, musholla and public toilets that were built were also tangible forms of development that involved the community so that in their care not only became the responsibility of the village government but the community was also involved in maintaining both cleanliness and security. Participation in the Margacinta village community in reviving culture is reflected in the presence of Saung Angklung Mang Koko and Padepokan Jenggala Manik, besides being a place to practice Sundanese traditional arts and culture, tourists can watch some Sundanese traditional musical instruments including angklung, kecapi, flute, and kendang. In addition to traditional musical instruments, tourists can also see and know some tools used by adults in ancient times (old-fashioned) such as dudukuy (straw woven hats and bamboo), hoes, machetes, and other tools.

\subsection{Conclusions}

From the results of the study entitled "Governance Innovation In Tourism Development Margacinta Pangandaran Village" it can be concluded that the concept of sustainable tourism in managing tourism in Badud Village has been innovating in terms of transformative leadership, the development of civil society tourism groups in Margacinta Village, various innovations in natural wealth and cultural products of Badud Village and the participation of the community to develop tourism together with the government.

\subsection{Suggestions}

Along with developing innovative tourism, there are still many shortcomings in tourism development that need to be addressed. To the Margacinta village government to pay more attention to infrastructure such as roads to tourist attractions, it is still minimal, hampering the mobilization of tourists who want to visit and Margacinta Village communities to increase participation especially in cultural development and preservation, specific in Kompepar Desa Margacinta membership and to utilize technological advances in tourism so that it can attract the wider community to visit Badud Village. 
Proceeding ICOGISS 2019

Page 373-387. ISBN: 978-602-6 988-75-1

Web Jurnal Online: jurnal.unmuhjember.ac.id

By: Mochamad Faizal R.;Fabya Budi Luthfiana

Governance Innovation In Tourism Development

Margacinta Village, Pangandaran Regency

\section{Reference}

Ardika, I Wayan. (2004). Bali Tourism: Building Culture and Tourism and Controlling the Culture of Tourism. Bali Towards Jagadhita: Various Perspectives. Denpasar: Bali Post Library page 20-33.

Emilda, Nia et al. (2016). Gondang Buhun Tradition Art as Character Education and Ecotourism: Efforts to Improve Community Welfare in Pangandaran Regency, West Java. Proceedings of the National Seminar on Research Results. ISBN 978-602-72894-5-1 Farr, James (2004), Social Capital: A Conceptual History, Political Theory, Vol 32 No. 1, pp.6-33.

Handoko, Hani, and Tjiptono. (1996). Transformational Leadership and Empowerment. Indonesian Journal of Economics and Business. Vol 11 no (1) ISSN 2338-5847

Fitra, Abdilah and Leksmono, S Maharani. (2001). "Sustainable tourism development", Journal of Tourism Science Vol.6, No. 1

Juliantara, Dadang (Ed.), (2000), Underflow of Democracy, Autonomy, and Village Empowerment, Yogyakarta: Lappera Main Library

Luthans, F. (1995). Organizational Behavior. Seventh Ed. Singapore: McGraw-Hill.

Madsen, Wendy and Cathy O'Mullan (2014), 'Knowing me, knowing you': Exploring the Effects of a Rural Leadership Program on Community Resilience, Rural Society, Vol. 23 No. 2, pp. 151-160.

Moleong, Lexy. (2001). Research methodology. Bandung: PT. Rosada Youth Works

Mubiyarto, (1984). Rural Development. Yogyakarta: UGM P3PK

Nugroho, Iwan and Rokhmin Dahuri. (2012). Development of Regional Economic, Social and Environmental Perspectives. Jakarta: LP3ES

Satria, Dias. (2009). Strategy for Developing Local Economic-Based Ecotourism in the Context of Poverty Alleviation Programs in Malang Regency. Journal of Indonesian Applied Economics. Vol 3 No (1) (37-34) do 10. 21776 / ub. Jiae.2009.003.01.5

Seftyono, Cahyo et al. (2016). Village Leadership and Management of Local Natural Resources in the Three Slopes of Gunung Ungaran Village, Central Java. Journal of Government Science Authority. Vol 6 (2) do 10. 266618 / ojip.v6i267 
Proceeding ICOGISS 2019

Page 373-387. ISBN: 978-602-6 988-75-1

Web Jurnal Online: jurnal.unmuhjember.ac.id

By: Mochamad Faizal R.;Fabya Budi Luthfiana

Governance Innovation In Tourism Development

Margacinta Village, Pangandaran Regency

Sumarto, Hetifah. 2004. Innovation, participation and good governance: 20 innovative and participatory workshops in Indonesia. Jakarta: Indonesian Torch Foundation

Yoeti, A Oka. (2007). Tourism Planning and Development. Jakarta: PT Pradnya Paramita.

Wiyonoputri, T Wiwien. (2005). Indonesian tourism. Tourism Culture and Culture Tourism.

Center for Tourism Planning and Development ITB 